\title{
High prevalence of occult hepatitis B among immigrant students in Canada: A case for universal immunization of young adults
}

\author{
ROSS A PENNIE, MD, FRCPC, C YONG KANG, PHD
}

\begin{abstract}
RA PENNIE, CY Kang. High prevalence of occult hepatitis B among immigrant students in Canada: A case for universal immunization of young adults. Can J Infect Dis 1993;4(2):105-107. The prevalence and demographic characteristics of positive hepatitis B (HBV) serology were determined among post secondary health care students in Ottawa, Ontario. HBV seropositivity was defined as the presence of HBV surface antigen (HBsAg) or antibodies to HBV core or surface antigens by radioimmunoassay. HBsAg-positive students were advised to visit their family doctors; the health measures that resulted were observed. Among 600 students born in North America, the proportion of HBV seropositive and HBsAg-positive were 0.8 and $0.2 \%$, respectively. Among the 63 students born outside Europe or North America, $22.2 \%$ were HBV seropositive (odds ratio 29.7, confidence interval 10.1 to 97.5 ) and $7.9 \%$ were HBsAg-positive (odds ratio 54.2, confidence interval 5.9 to 2568.3). Of the seven HBsAg-positive students, none had known their HBV status - five visited their doctors, two of whom sought and immunized susceptible household contacts. This survey supports the view that many sexually active young adults integrating into Canadian society from immigrant families are unknowingly HBsAg-positive, and when their HBV status is identified to them and their doctors, appropriate measures for the protection of close contacts are often overlooked. Physician education about the management of HBV carriers should be improved and consideration given to the universal HBV immunization of young adults.
\end{abstract}

Key Words: Adolescents, Hepatitis B, Immunization, Infection control, Vaccine

\section{Forte prévalence d'hépatite B occulte chez les étudiants immigrants au Canada : un argument en faveur de la vaccination générale des jeunes adultes}

RÉSUMÉ: La prêvalence et les caractêristiques démographiques de la séropositivité à l'hépatite B (HBV) ont été déterminées chez des étudiante en soins de santé post-secondaires à Ottawa (Ontario). La séropositivité HBV a été définie comme la présence d'antigènes de surface HBV (HBsAg) ou d'anticorps aux antigènes nucléocapsidiques ou de surface HBV par radio-immunodosage. Il a été conseillé aux étudiants HBsAg positifs de consulter leur médecin de famille; les mesures sanitaires qui en ont résulté ont été observées. Parmi les 600 étudiants nés en Amérique du Nord, la proportion des HBV séropositifs et des

Department of Paediatrics, Faculty of Medicine; and Department of Microbiology and Immunology, Faculty of Medicine, University of Ottawa, Ontario

Correspondence and reprints: Dr RA Pennie, Infectious Diseases and Microbiology. Room 3N27G, McMaster University Medical Centre, 1200 Main Street West, Hamilton, Ontario L8N 3Z5. Telephone (416) 521-2100 ext 6610

Received for publication March 23, 1992. Accepted June 4, 1992 
HBsAg positifs a été de 0,8 et 0,2\%, respectivement. Parmi les 63 étudiants nés hors d'Europe ou d'Amérique du Nord, 22,2 \% étaient HBV séropositifs (rapport des chances 29,7; intervalle de confiance 10,1 à 97,5) et 7,9\% étaient HBsAg positifs (rapport de chances 54,2; intervalle de confiance 5,9 à 2568,3 ). Aucun des étudiants HBsAg positifs n'était au courant de son état HBV. Cinq ont rendu visite à leur médecin; deux des médecins ont recherché et fait vacciner les contacts familiaux exposés. Cette enquête confirme le fait que de nombreux jeunes adultes sexuellement actifs en provenance de familles d'immigrants et s'intégrant dans la société canadienne, sont HbsAg positifs sans le savoir; quand leur état HBV leur est révélé, ainsi qu'à leur médecin, les mesures de protection appropriées concernant les contacte proches sont souvent négligées. L'information des médecins au sujet du traitement des porteurs d'HBV doit être améliorée, et l'on doit envisager la vaccination HBV générale des jeunes adultes.

$\mathrm{D}$ ESPITE THE LICENSURE OF A SAFE AND EFFICACIOUS hepatitis B (HBV) vaccine in Canada in 1982, the annual incidence of new cases of acute HBV infection rose steadily from 1982 to 1989 (1). The 20- to 29-yearold age group had the highest and most rapidly rising incidence. Sexual intercourse is an efficient method of HBV transmission (reported after a single sexual encounter [2]) and heterosexual contact appears to play a major role in disease transmission among young adults $(1,3)$.

Thirty-five per cent of acute cases of HBV in the United States occur in adults without any recognized risk factor, but little is known about the demographic characteristics of adult HBV infection among Canadians. Health measures taken by newly identified HBV carriers, such as notification and immunization of contacts, have not been studied.

During a comparative trial of HBV vaccines among health care students in Ottawa, Ontario in 1989 (4), we determined the demographic characteristics and HBV status of almost 700 post secondary students, and observed the health measures taken by those found to be positive for hepatitis B surface antigen (HBsAg).

\section{SUBJECTS AND METHODS}

In September 1989, after approval by the Ethics Committee of the University of Ottawa, students enrolled in six health care disciplines at the community college and university level in Ottawa, Ontario were offered participation in an experimental HBV immunization program (4). Students were informed of the dates of immunization sessions and were asked to attend if they wished to receive HBV vaccine, had no known history of hepatitis B infection and had not received any previous hepatitis B immune globulin or vaccine. The country of birth of participating students and their parents were recorded. A blood sample was drawn prior to immunization for measurement of HBsAg, antibody to hepatitis B core antigen (anti-HBc) and antibody to HBsAg (anti-HBs) using commercially available radioimmunoassay kits (Abbott Laboratories).

Students with at least one positive HBV serological test were interviewed in person by the principal investigator regarding marital status and risk factors for acquisition of HBV. In addition, HBsAg-positive students were provided with a letter explaining that they

\begin{tabular}{|c|c|c|c|c|}
\hline & $\begin{array}{c}\text { No. of } \\
\text { students } \\
(\%)\end{array}$ & $\begin{array}{c}\text { Previously } \\
\text { infected } \\
(\%)^{\dagger}\end{array}$ & $\begin{array}{l}\text { HBsAg- } \\
\text { positive } \\
\text { (\%) }\end{array}$ & $\begin{array}{c}\text { Immune } \\
\text { non- } \\
\text { carriers (\%) }\end{array}$ \\
\hline \multicolumn{5}{|c|}{ Place of birth } \\
\hline All places & $693(100)$ & $20(2.9)$ & $7(1)$ & $13(1.9)$ \\
\hline $\begin{array}{l}\text { Canada/ } \\
\text { USA }\end{array}$ & $600(87)$ & $5(0.8)$ & $1(0.2)$ & $4(0.7)$ \\
\hline Europe & $30(4)$ & $1(3.3)$ & $1(3.3)$ & 0 \\
\hline Other & $63(9)$ & $14(22.2)$ & $5(7.9)$ & $9(14.3)$ \\
\hline \multicolumn{5}{|l|}{ Age (years) } \\
\hline Median & 21 & 25 & 25 & 24 \\
\hline Range & $17-48$ & $19-48$ & $20-35$ & $19-48$ \\
\hline Males (\%) & 25 & 35 & 14 & 46 \\
\hline
\end{tabular}

*University of Ottawa and Algonquin College of Applied Arts and Technology. ${ }^{t}$ Positive tests for antibodies to hepatitis $B$ core or surface antigens, or HBsAg-positive: ${ }^{\ddagger}$ Positive tests for antibodies to hepatitis $B$ core or surface antigens, and HBsAg-negative. HBsAg Hepatitis B surface antgen

were potentially infectious to sexual and household contacts including newborn infants, they should use condoms during sexual intercourse with partners not known to be immune to HBV, and they should take the letter to their family doctor and ask that household contacts and regular sexual partners be tested for HBV and be immunized if not previously infected.

Nine months later, the HBsAg-positive students were surveyed by telephone regarding the status of family members and sexual partners with respect to HBV serology and immunization.

The two-tailed Fisher exact test was applied to HBV serology results to test for differences in HBV seroprevalence between demographic groups and exact confidence limits for odds ratios were calculated according to the method of Mehta et al (5).

\section{RESULTS}

Of the 1341 students registered in six health care disciplines, 693 (52\%) presented for hepatitis B immunization. Of these, $20(2.9 \%)$ had evidence of previous HBV infection. Seven (1.0\%) were HBsAg-positive and $13(1.9 \%)$ were immune noncarriers (negative for HBsAg but positive for anti-HBs or anti-HBc).

Table 1 illustrates the HBV status in relation to place 
of birth. Rates of previous HBV infection and HBsAgpositivity in the 600 students born in North America were 0.8 and $0.2 \%$, respectively. Among the 63 students born outside North America or Europe, the rate of previous infection was $22.2 \%$ (odds ratio $29.7,95 \%$ confidence interval 10.1 to 97.5) and the rate of HBsAgpositivity was $7.9 \%$ (odds ratio 54.2 , confidence interval 5.9 to 2568.3 ). When the 39 students born in the Orient, Black Africa and Haiti were considered together, the rates of previous HBV infection and HBsAg-positivity were 25.6 and $12.8 \%$, respectively.

During interviews of the $20 \mathrm{HBV}$-seropositive students, none admitted to medical factors or a lifestyle that increased the risk of HBV acquisition, and none had known their HBV status. The follow-up questionnaire of the seven HBsAg-positive students revealed that five visited their family physicians, and that doctors arranged for the testing and immunization of susceptible contacts of only two HBsAg-positive students.

\section{DISCUSSION}

This study demonstrated that HBV carriers and doctors appear to take inadequate measures to prevent HBV transmission. Even when HBsAg-positive individuals were identified and explicitly counselled in this study, the family contacts of only two of seven students were tested and immunized. Guidelines should be disseminated in order to increase doctors' awareness of how to manage HBV carriers, their families and con-

ACKNOWLEDGEMENT: This study was supported by Ontario Ministry of Health research grant \#02503.

\section{REFERENCES}

1. Carter AO, Walsh P. Hepatitis B in Canada: Surveillance summary. Can Dis Weekly Rep 1991;17:166-71.

2. Wright RA. Hepatitis B and the HBsAg Carrier: An outbreak related to sexual contact. JAMA 1975:232:717-21.

3. Alter MJ, Hadler SC, Margolis HS, et al. The changing epidemiology of hepatitis B in the United States: Need for alternative vaccination strategies. JAMA 1990;263:1218-22.

4. Pennie RA, O'Connor AM, Dulberg CS, Bottiglia A, Manga $\mathrm{P}$, Kang CY. Low-cost hepatitis B vaccine improves uptake among self-paying health-care students. J Med Virol 1992;37:48-53.

5. Mehta CR, Patel NR, Gray R. Computing an exact confidence-interval for the common odds ratio in several $2 \times 2$ contingency tables. J Am Stat Assoc 1985;80:969-73.

6. Immunization Practices Advisory Committee (ACIP). Recommendations for protection against viral hepatitis. MMWR 1985;34:313-35.

7. Palmer-Beasley R, Lin C-C, Hwang L-Y, Chien C-S. tacts. As HBV is a reportable disease, perhaps medical officers of health have a role in HBV contact-tracing.

The $22.2 \% \mathrm{HBV}$ seroprevalence rate among the study participants born outside North America and Europe reflected the high HBV seroprevalence reported previously from sub-Saharan Africa and the Far East (6-8). Three-quarters of immigrants to Canada now come from Asia, Africa and Latin America $(9,10)$, therefore, significant numbers of HBV carriers settle in Canada each year.

HBV-infected immigrant parents can transmit the virus to their children who blend into the Canadian mosaic in daycare centres and schools. There is no program of HBV screening of immigrant children in Canada and immigrant children may not be perceived at risk of transmitting HBV. However, efficient transmission of HBV in classrooms not involving mentally retarded children does occur $(11,12)$.

In July 1991, the National Advisory Committee on Immunization stated that HBV immunization in Canada should be universal (13). No specific program was recommended because the issues of scheduling and high vaccine cost remained unresolved. Given that heterosexual contact plays an important role in HBV transmission the present survey suggests that sufficient numbers of sexually active young people in Canada are occult, infectious carriers of HBV to warrant the inclusion of adolescents or young adults in any new schedule of universal HBV immunization.

Hepatocellular carcinoma and hepatitis B virus: A prospective study of 22,707 men in Taiwan. Lancet 1981;ii:1129-32.

8. Lange RW, Frame JD. High incidence of viral hepatitis among American missionaries in Africa. Am J Trop Med Hyg 1990;43:527-33.

9. Simmons, A.B. The New wave of immigrants to Canada: Trends in country of origin and implications for the future. In: The Review of Demography and its Implications for Economic and Social Policy, Update Number Five. Ottawa: The Royal Society of Canada, 1988:70

10. Joint Task Force on Services to Minority Ethnic Groups. The changing policy context. In: Yau A, Schonenbach P, eds. Strengthening the Network of Services to Minority Ethnic Groups in Ottawa-Carleton. Ottawa: Social Planning Council of Ottawa-Carleton, 1989:14-5.

11. Milne A, Allwood GK, Moyes CD, Pearce NE, Lucas CR. Prevalence of hepatitis B infection in a multiracial New Zealand community. NZ Med J 1985:98:529-32.

12. Milne A, Moyer LA. Hepatitis B carriage in children. NZ Med J 1983;96:238-41.

13. National Advisory Committee on Immunization (NACI). Statement on universal immunization against hepatitis B. Can Dis Weekly Rep 1991;17:165. 


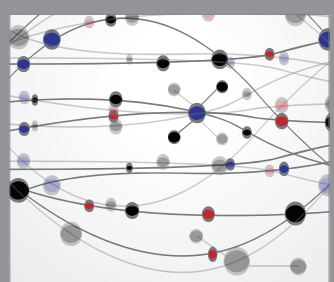

The Scientific World Journal
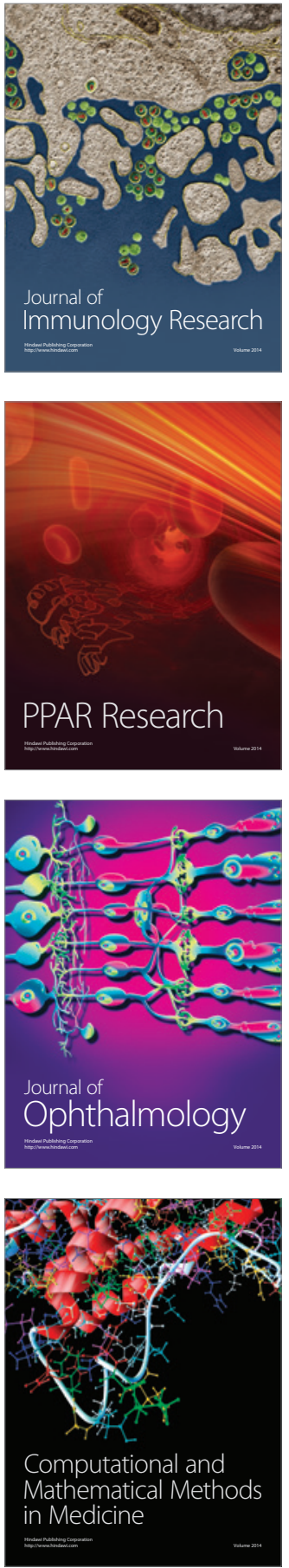

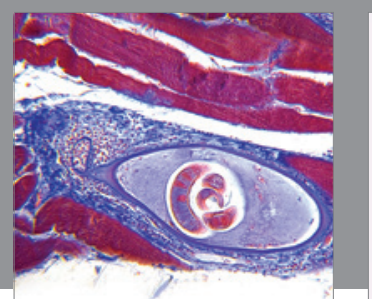

Gastroenterology Research and Practice

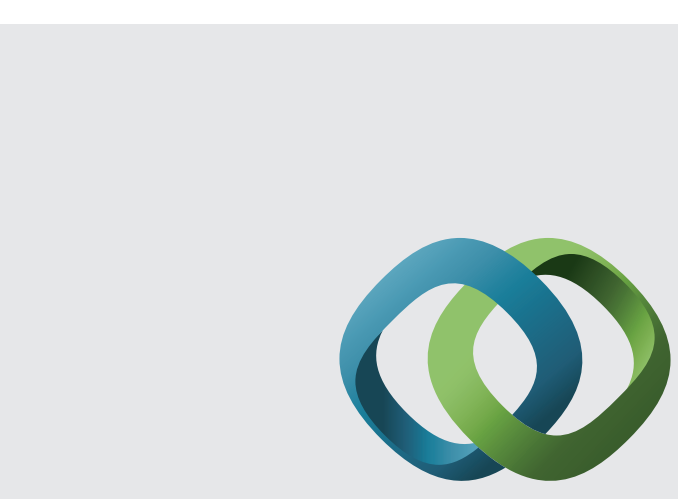

\section{Hindawi}

Submit your manuscripts at

http://www.hindawi.com
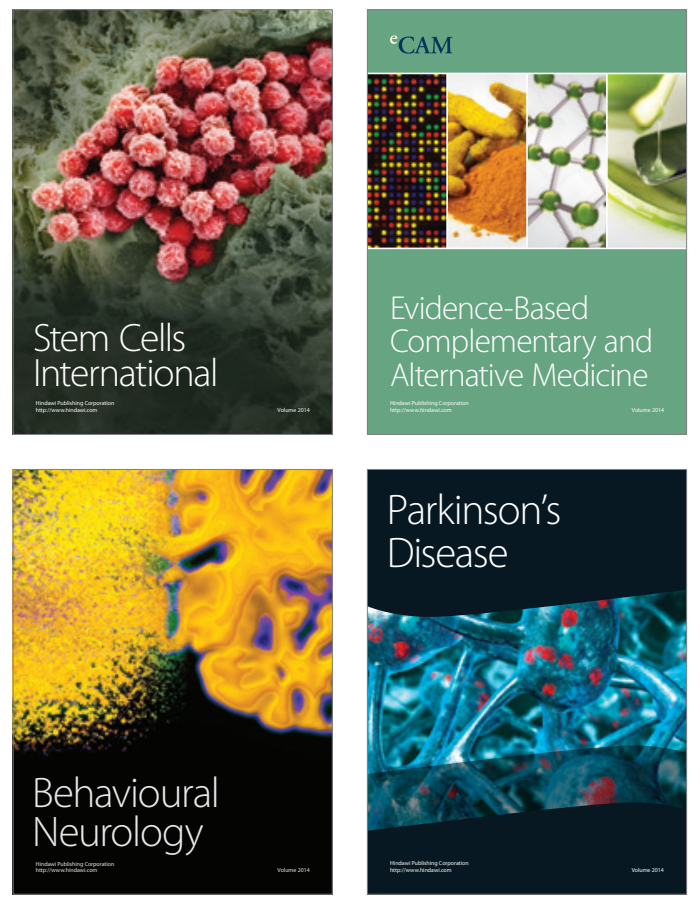
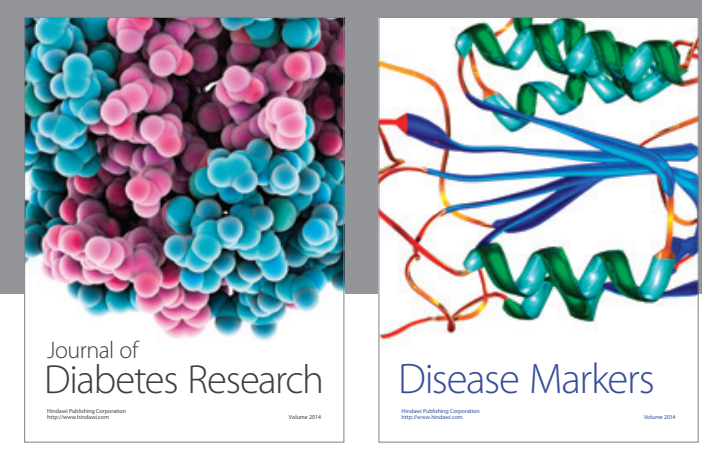

Disease Markers
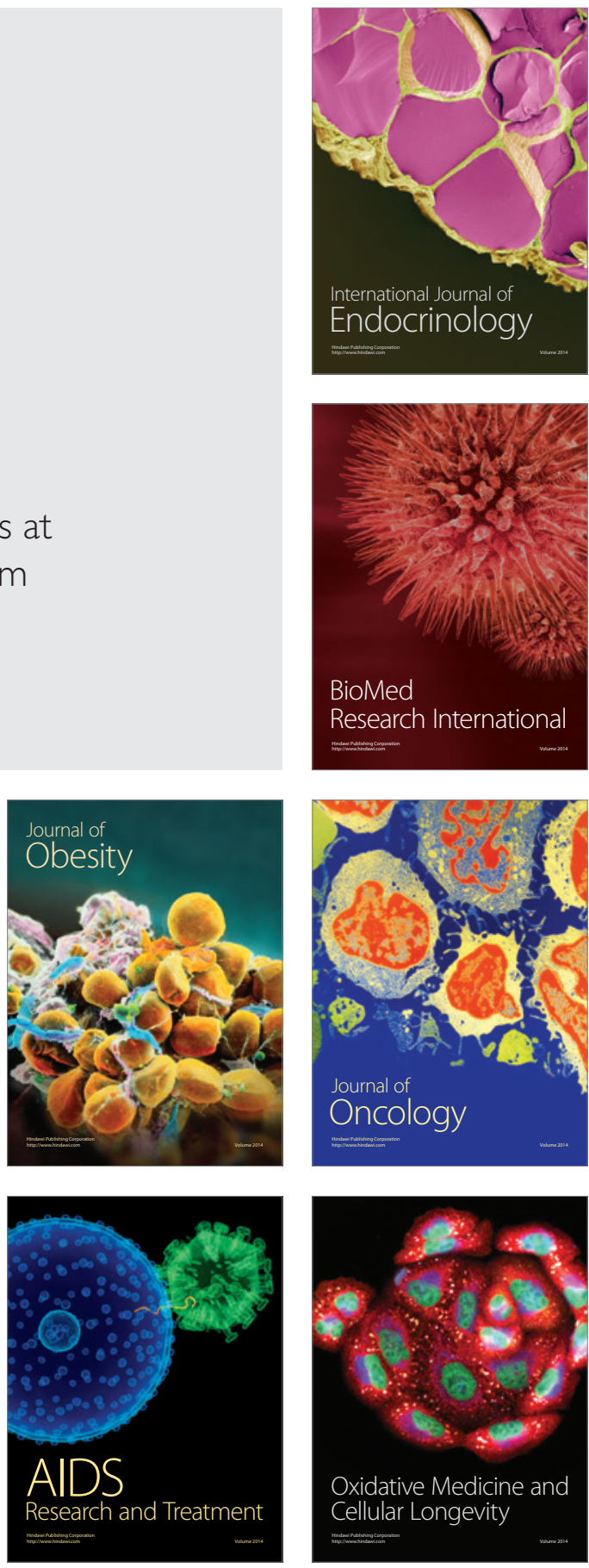